\title{
Pembelajaran Daring: Tantangan Pembentukan Karakter dan Spiritual Peserta Didik
}

\author{
Sister Buulolo ${ }^{1}$, Nelci Kual, ${ }^{2}$ Rolan Marthin Sina, ${ }^{3}$ Hendro H. Siburian ${ }^{4}$ \\ 1,2,3,4 Sekolah Tinggi Teologi Tawangmangu \\ 1sisterbuulolo@gmail.com
}

\begin{abstract}
Online learning is a solution for the implementation of the teaching and learning process in the current pandemic era. In online learning, there are challenges in building the character and spirituality of students. Character and spiritual formation of students is generally done by direct interaction between educators and students in the class. The purpose of this research is to look at learning challenges and provide solutions. The qualitative descriptive method chosen in this study, because the researcher seeks to collect data and understand the meaning of an event or phenomenon that is the subject of observation and occurs in real or in full in the field so that conclusions can be drawn. The results of the study prove that students are hampered in following the online learning process, educators are less creative in utilizing online learning, there is no learning material that can be used as a benchmark for students and educators and the lack of supporting facilities in the online learning process.
\end{abstract}

Keywords: Character, Students, Online learning, Spiritual

Abstrak: Pembelajaran daring (dalam jaringan) menjadi solusi pelaksanaan proses belajar mengajar dimasa pandemi yang melanda dunia masa ini. Dalam pembelajaran daring menemui tantangan dalam pembentukan karakter dan spiritual peserta didik. Pembentukan karakter dan spiritual peserta didik umumnya dilakukan dengan adanya interaksi langsung antara pendidik dan peserta didik di kelas. Tujuan penelitian ini untuk melihat tantangan pembelajaran dan memberikan solusi. Metode deskriptif kualitatif yang dipilih dalam penelitian ini, karena peneliti berupaya mengumpulkan data dan memahami makna dari suatu peristiwa atau fenomena yang menjadi pokok pengamatan serta terjadi secara real maupun secara utuh di lapangan sehingga dapat ditarik kesimpulan. Hasil penelitian membuktikan bahwa peserta didik terhambat dalam mengikuti proses pembelajaran daring, pendidik kurang kreatif dalam memanfaatkan pembelajaran daring, tidak adanya meteri pembelajaran yang dapat menjadi patokan bagi peserta didik dan pendidik serta kurang tersedianya sarana penunjang dalam proses pembelajaran daring.

Kata Kunci: Karakter, Pembelajaran Daring, Peserta Didik, Spiritual;

$\begin{array}{llll}\text { Article History : } & \text { Received: 08-11-2020 } & \text { Revised: 29-12-2020 } & \text { Accepted: 29-12-2020 }\end{array}$

\section{Pendahuluan}

Wabah corona virus disease (covid-19) telah menyebar hampir seluruh negara di dunia termasuk negara Indonesia. Dampaknya dirasakan pada berbagai sendi kehidupan 
termasuk lembaga pendidikan, khususnya Perguruan Tinggi. Pada tanggal 2 Maret 2020, pemerintah Indonesia melalui Presiden Joko Widodo mengumumkan kasus pertama covid-19. Dua warga negara Indonesia dinyatakan positif covid-19 setelah melakukan kontak langsung dengan warga negara Jepang yang datang ke Indonesia. ${ }^{1}$ Untuk menghambat laju penularan covid-19, pemerintah mengeluarkan beberapa kebijakan seperti larangan berkerumun, pembatasan sosial (social distancing) dan pembatasan jarak fisik (physical distancing), selalu memakai masker, rajin mencuci tangan dan sebagainya. Kementerian Pendidikan dan Kebudayaan dalam surat edaran Kemendikbud Dikti No. 1 tahun 2020 juga melarang sekolah-sekolah dan perguruan tinggi untuk melakukan proses pembelajaran secara langsung atau tatap muka. Salah satu alternatif pembelajaran yang ditawarkan ialah menyelenggarakan pembelajaran melalui daring atau secara online. ${ }^{2}$

Ali Sadikin dkk dalam jurnal BIODIK, mengutip pendapat Moore, Dickson-Deane, dan Galyen yang mengatakan bahwa pembelajaran daring merupakan pembelajaran yang menggunakan jaringan internet dengan akses, konektif, fleksibel, dan kemampuan untuk memunculkan berbagai jenis interaksi pembelajaran. ${ }^{3}$ Pembelajaran daring menghubungkan peserta didik dengan sumber belajarnya dengan jarak jauh namun dapat saling berkomunikasi, berinteraksi dengan menggunakan teknologi informasi dan komunikasi di antaranya aplikasi Zoom, Google Classroom, Google Meeting dan aplikasi lainnya dengan memanfaatkan jaringan internet.

Sekolah Tinggi Teologi Tawangmangu (STT Tawangmangu) merupakan sekolah yang berciri pembentukan karakter dan spiritual. Semua program yang dilaksanakan oleh STT Tawangmangu selalu menekankan pembentukan karakter dan spiritual. Namun, kegiatan proses pembelajaran mengalami kendala dikarenakan penyebaran covid-19. Sesuai arahan pemerintah maka STT Tawangmangu juga melakukan sistem pembelajaran daring. Berdasarkan hasil pengamatan dari peneliti secara langsung, pelaksanaan pembelajaran daring Sekolah Tinggi Teologi Tawangmangu diingkat 1 sampai tingkat 4 ditemukan banyak kendala-kendala dalam melaksanakan pembelajaran daring baik ketersediaan sarana prasarana pembelajaran daring, kesiapan

1 CNN Indonesia, "Jokowi Umumkan Dua Orang WNI Positif Corona Di Indonesia," 2020, https://www.cnnindonesia.com/nasional/20200302111534-20-479660/jokowi-umumkan-dua-wnipositif-corona-di-indonesia.

${ }^{2}$ Kementerian Pendidikan dan Kebudayaan, "Surat Edaran Direktorat Jenderal Pendidikan Tinggi Kemdikbud Nomor 1 Tahun 2020," last modified 2020, http://lldikti3.kemdikbud.go.id/v6/wpcontent/uploads/2020/04/Surat-Edaran-Direktorat-Jenderal-Pendidikan-Tinggi-Kemdikbud-Nomor-1Tahun-2020-3.pdf.

3 Ali Sadikin and Afreni Hamidah, "Pembelajaran Daring Di Tengah Wabah Covid-19," BIODIK: Jurnal Ilmiah Pendidikan Biologi 6, no. 2 (2020): 216. 
pendidik maupun peserta didik dalam mengikuti pembelajaran daring. Dalam proses pelaksanaan pembelajaran daring, interaksi pendidik dan peserta didik tidak efektif sehingga peserta didik banyak yang bermain dan tidak fokus.

Dari hasil wawancara terhadap pendidik, peneliti menemukan bahwa pendidik mengalami kesulitan dalam mengawasi maupun mengarahkan peserta didik untuk mengikuti pembelajaran secara daring. Pendidik juga kesulitan dalam memberikan penguatan kepada peserta didik, disebabkan karena tidak dapat berinteraksi langsung. ${ }^{4}$ Senada dengan hasil wawancara dengan pendidik, peneliti juga melakukan wawancara dengan peserta didik tingkat 1 sampai tingkat 4, sebagian besar berpendapat bahwa pembelajaran daring yang dilakukan di Sekolah Tinggi Teologi Tawangmangu sangat kurang efektif baik dalam transfer pengetahuan maupun dalam membangun ikatan emosional dengan pendidik. Mayoritas peserta didik tingkat 1 sampai tingkat 4 menyatakan bahwa sarana prasarana masih kurang memadai, dan peserta didik tidak dapat berinteraksi langsung dengan pendidik, sehingga tidak adanya ikatan emosional yang baik, tidak ada kebersamaan, dan tidak ada waktu sharing. ${ }^{5}$

Berdasarkan hasil temuan dari peneliti, menyimpulkan bahwa pelaksanaan proses pembelajaran daring di STT Tawangmangu kurang efektif dalam pembentukan karakter dan spiritual peserta didik. Sehingga perlu dicari solusi untuk menyelesaikan masalah kurang efektifnya pembelajaran daring dalam membentuk karakter dan spiritual peserta didik di STT TAWANGMANGU.

\section{Metode Penelitian}

Penelitian ini menggunakan metode deskriptif kualitatif. Pendekatan deskriptif kualitatif adalah upaya memahami makna dari suatu peristiwa atau fenomena yang menjadi pokok pengamatan, terjadi secara nyata dan secara utuh di lapangan sehingga dapat ditarik kesimpulan. Pengumpulan data penelitian menggunakan; Pertama, observasi (pengamatan), peneliti melakukan pengamatan pelaksanaan proses pembelajaran daring di STT Tawangmangu. Kedua, wawancara (interview), peneliti melakukan wawancara dengan penanggungjawab penyelenggaraan pembelajaran daring dari satuan pendidikan, wawancara dengan pendidik dan dengan peserta didik untuk menunjang data-data yang diperlukan dalam penelitian ini. ${ }^{6}$ Sehingga data penelitian didapat secara langsung dari pelaksana pendidikan, pelaksana pembelajaran daring dan

\footnotetext{
${ }^{4}$ Wawancara dengan Pendidik, Senin, 02 November 2020, Jam. 16.50-17.30

${ }^{5}$ Wawancara dengan Peserta Didik, Jumat 28 Oktober 2020, Jam 10.00-12.50.

${ }^{6}$ Lexy J. Moleong, Metodologi Penelitian Kualitatif (Bandung: PT Remaja Rosdakarya, 2000), 3.
} 
peserta didik. Sehingga data-data yang diperoleh dapat dianalisis dan bisa ditarik kesimpulan.

\section{Hasil dan Pembahasan}

Berdasarkan penelitian sebelumnya yang dilakukan oleh I Wayan E. Santika mengenai "Pendidikan Karakter Pada Pembelajaran Daring" dimana pendidikan karakter tidak hanya dilihat dari ranah kognitif saja melainkan memiliki keseimbangan kognitif, afektif, dan psikomotorik. Ketiga hal tersebut, akan menyeimbangkan peserta didik untuk lebih mudah mengaktualisasikan nilai-nilai karakter dalam kehidupannya. ${ }^{7}$ Berdasarkan hasil penelitian sebelumnya, peneliti ingin melakukan penelitian lanjutan dimana tidak hanya ingin melihat pembentukan karakter tetapi juga pembentukan spiritual peserta didik.

Daring adalah singkatan dari dalam jaringan (online) dengan menggunakan jaringan internet. Pembelajaran memanfaatkan teknologi sebagai media pembelajaran tanpa melakukan interaksi secara langsung (tatap muka). Beberapa aplikasi popular yang digunakan antara lain zoom, google meeting, google classroom, dan lain-lain. Pembelajaran daring adalah proses pembelajaran yang dilakukan melalui jarak jauh lewat media yang berupa internet dan alat penunjang lainnya. ${ }^{8}$

Beberapa pandangan para ahli mengenai pengertian pembelajaran daring, antara lain: Definisi pembelajaran daring menurut Khan yaitu "Online learning instruction as an innovative approach for delivering instruction to a remote audience, using the Web as the medium". ${ }^{9}$ Sedangkan, Kramer mendefinisikan pembelajaran daring sebagai sistem pembelajaran jarak jauh yang menghubungkan peserta didik dengan sumber belajar di sebuah ruang elektronik yang sama pada waktu yang sama. Gross searah dengan itu, namun menitikberatkan penggunaan media teknologi seperti video, audio, komunikasi multimedia atau kombinasi dari teknologi tersebut. ${ }^{10}$

Horton (2006) mengemukakan sisi positif pembelajaran e-learning yakni mengurangi kebosanan peserta didik akibat dominasi pengajar dalam pembelajaran tatap muka. Media pembelajaran yang digunakan ialah teknologi informasi dan komputer. Kartasasmita (2003) menambahkan, penggunaan internet sebagai e-learning

\footnotetext{
${ }^{7}$ I Wayan Eka Santika, "Pendidikan Karakter Pada Pembelajaran Daring," IVCEJ: Indonesian Values and Character Education Journal 3, no. 1 (2020): 8-16.

${ }^{8}$ Hilna Putria dkk, "Analisis Proses Pembelajaran Dalam Jaringan (Daring) Masa Pandemi COVID-19 Pada Guru Sekolah Dasar," Basicedu : Jurnal of Elementary Education 4, no. 4 (2020): 862-863.

${ }^{9}$ Meda Yuliani and Janner Simamata, Pembelajaran Daring Untuk Pendidikan Teori Dan Penerapan (Medan: Yayasan Kita Menulis, 2020), 3.

${ }^{10}$ Ridwan Sanjaya, 21 Refleksi Pembelajaran Daring Di Masa Darurat (Semarang: Universitas Katolik Soegijapranata, 2020), 71-72.
} 
memudahkan peserta didik untuk mendapatkan akses ke sumber belajar, ke pengajar dan sesama peserta didik. Oleh sebab itu, istilah e-learning sering disamakan dengan online course, online learning, internet enabled learning, virtual learning atau web-based learning. ${ }^{11}$

\section{Pembelajaran Konvensional dan Pembelajaran Daring}

Sebelum lebih jauh pembahasan mengenai kelebihan dan kekurangan pembelajaran daring, penulis ingin menilik perbedaan yang mencolok dalam proses pembelajaran konvensional dan daring. Pembelajaran konvensional merupakan pembelajaran tatap muka di kelas dengan menggunakan berbagai metode seperti menjelaskan, penugasan, serta tanya jawab. Sedangkan pembelajaran daring berbasis teknologi yang mana materi ajar dikirim secara elektronik ke peserta didik dengan memanfaatkan jaringan internet dan aplikasi-aplikasi lainnya.

Adapun kelebihan pembelajaran konvensional adalah sebagai berikut; peserta didik akan memiliki respon balik yang cepat, sudah familiar bagi pendidik dan peserta didik. Kekurangan dari pembelajaran ini adalah peserta didik terlalu tergantung kepada pendidik, terbatas oleh waktu, semakin hari biaya pembelajaran juga semakin meningkat. Sedangkan kelebihan pembelajaran daring adalah memberikan keuntungan pada pembelajaran yang berpusat serta melatih kemandirian dalam mengelola waktu dan lokasi yang fleksibel, biayanya yang sangat terjangkau untuk para peserta didik dan juga memberikan akses yang tidak terbatas dalam mengembangkan pengetahuan peserta didik. Kekurangan pembelajaran daring ialah kurangnya respon dalam proses belajar mengajar, pengajar harus memiliki waktu yang lebih lama untuk mempersiapkan diri dan membuat pendidik maupun peserta didik merasa tidak nyaman dengan munculnya perilaku frustasi, kecemasan dan kebingungan. ${ }^{12}$

Dari pembahasan di atas dapat disimpulkan bahwa metode pembelajaran daring dan pembelajaran konvensional memiliki keuntungan dan kekurangan yang sangat beragam. Namun, dengan adanya pandemi covid-19 yang melanda seluruh dunia, mengharuskan dunia pendidikan mengalami perubahan dalam proses belajar mengajar. Pembelajaran daring bukanlah suatu hal yang baru, karena untuk Indonesia sendiri, telah mengalami kemajuan secara teknologi dengan adanya perkembangan industri 4.0,

\footnotetext{
${ }^{11}$ Lidia Simanihuru and Dkk, E-Learning (Medan: Yayasan Kita Menulis, 2019), 4-5.

12 "Faktor-Faktor Yang Mempengaruhi Kesuksesan Pembelajaran Daring Dalam Revolusi Industri 4.0," SAINTEKS : Seminar Nasional Teknologi Komputer Dan Sains, 57.
} 
namun tidak semua pendidikan sudah menerapkan pembelajaran daring sebelum covid19.

\section{Standar Operasional Pelaksanaan Pembelajaran Daring di STT Tawangmangu}

Tersebarnya Covid-19 di Indonesia sampai saat ini terus meningkat dan bahkan belum menunjukkan tanda-tanda penurunan. Untuk itu Menteri Pendidikan dan Kebudayaan di Indonesia, mengambil beberapa tindakan sebagai bentuk pencegahan penularan di lingkungan pendidikan, yakni dengan menerbitkan Surat Keputusan mengenai proses pembelajaran khususnya pendidikan tinggi pada semester gazal tahun akademik 2020/2021 disemua zona wajib untuk dilaksanakan secara daring pada mata kuliah teori dan praktik, dan hal ini telah disepakati bersama oleh empat menteri. Kebijakan ini ditetapkan sebagai bentuk pencegahan terhadap kampus yang menjadi klaster baru dalam penyebaran Covid-19. Adapun perencanaan penyelenggaraan pembelajaran daring antara lain: belajar secara individu atau mandiri, namun hal ini akan terbimbing atau diarahkan dengan menggunakan beragam sumber belajar, melakukan evaluasi dan asesmen, juga memanfaatkan Teknologi Informasi dan Komunikasi (TIK), serta menggunakan sumber belajar dalam bentuk bahan ajar cetak dan noncetak. ${ }^{13}$

Berdasarkan keputusan Kementerian Pendidikan dan Kebudayaan, maka STT Tawangmangu menyelenggarakan pembelajaran secara daring melalui tiga tahapan yaitu persiapan, pelaksanaan dan penilaian.

\section{Persiapan Pembelajaran Daring}

Persiapan pembelajaran daring oleh dosen. Tahapan ini merupakan langkah awal dalam pelaksanaan pembelajaran daring yang dapat mendukung dosen dalam menyampaikan materi ajar. Sehingga, para dosen perlu mempersiapkan perangkat keras seperti laptop, earphone atau headset, handphone dan perangkat lunak (web browser, aplikasi yang akan digunakan) yang kompatibel. Perlu juga untuk mempersiapkan koneksi internet yang sesuai dengan standar video meeting, karena hal ini sangat mendukung terlaksana atau tidaknya proses pembelajaran. Serta mempersiapkan materi perkuliahan dalam bentuk soft file seperti power point, video, doc, maupun bentuk yang lainnya sesuai dengan perencanaan di tiap pertemuan.

Dengan memahami langkah-langkah penggunaan media pembelajaran secara daring dan mengenai perlunya persiapan pembelajaran daring, hal ini juga berlaku

13 Direktorat Pembelajaran dan Kemahasiswaan, Direktorat Jenderal Pendidikan Tinggi, and Kementerian Pendidikan dan Kebudayaan RI, Panduan Penyelenggaraan Pembelajaran Semester Gasal 2020/2021 Di Perguruan Tinggi, 2020, 3-4. 
untuk mahasiswa STT Tawangmangu dalam mempersiapkan beberapa hal seperti yang dipersiapkan oleh dosen, antara lain: pertama, menyiapkan perangkat keras dan perangkat lunak yang kompatibel. Kedua, mempersiapkan koneksi internet yang sesuai dengan standar video meeting. Ketiga, memahami penggunaan media pembelajaran secara daring.

\section{Pelaksanaan Pembelajaran Daring}

Proses pembelajaran daring dilaksanakan oleh dosen dan mahasiswa secara terencana dan tersistem. Adapun tahap-tahap pelaksanaan kegiatan seperti: kegiatan perkuliahan sesuai jadwal. Dosen dapat menggunakan virtual class dan video conference sesuai dengan kemampuan yang dimiliki. Untuk memastikan kehadiran mahasiswa, maka langkah yang ditempuh ialah dosen meminta mahasiswa mengirimkan screenshoot kehadiran di kelas virtual. Mengenai materi pembelajaran, hal itu dilakukan sesuai dengan perecanaan. Serta ada bukti proses interaksi antara dosen dengan mahasiswa, dosen menyerahkan absensi mahasiswa dan bukti perkuliahan ke akademik program studi atau jurusan. Pelaksanaan dari pembelajaran daring juga mengikuti jadwal perkuliahan yang ditentukan setiap prodi. Sepanjang proses pembelajaran daring, seluruh mahasiswa harus taat atau melaksanakan tata tertib perkuliahan secara daring yang telah ditetapkan, serta mahasiswa juga dituntut untuk dapat membangun komunikasi secara dua arah selama proses pelaksanaan pembelajaran daring.

\section{Penilaian Hasil Pembelajaran Daring}

Pelaksanaan perkuliahan secara daring terlaksana atau tidaknya didukung pada hasil akhir dari peserta didik dalam mengolah materi ajar yang diberikan. Untuk itu, setiap dosen wajib memberikan penilaian terhadap hasil ujian dan tugas mahasiswa, dan teknik penilaian sesuai dengan instrument yang telah ditetapkan, yang sesuai dengan Capaian Pembelajaran Mata Kuliah (CPMK) yang dibebankan pada setiap mata kuliah. ${ }^{14}$

\section{Karakter dan Spiritual Peserta Didik}

Secara umum, karakter adalah sebagai sifat-sifat kejiwaan, akhlak, atau budi pekerti yang membedakan seseorang dari orang lain. Secara etimologi kata, istilah karakter

\footnotetext{
${ }^{14}$ Sekolah Tinggi Teologi Tawangmangu, Panduan Pembelajaran Daring, 2020, 4-6.
} 
berasal dari bahasa Yunani, charassein, yang berarti to engrave atau mengukir. ${ }^{15}$ Sedangkan menurut Masnur, karakter adalah cara seseorang berpikir dan berperilaku dalam kehidupan sehari-hari. ${ }^{16}$ Artinya untuk melihat karakter seseorang maka kita harus melihat apa yang nampak, baik itu perilakunya, tindakanya dan apa yang diungkapkan lewat ucapan. Jadi karakter peserta didik yang dimaksud dalam penelitian ini adalah ciri khas seorang peserta didik dalam berpikir dan berperilaku di dalam interaksinya dengan orang-orang di lingkungannya.

Sedangkan pengertian spiritual dalam KBBI, berhubungan dengan sifat kejiwaan (rohani, batin) ${ }^{17}$ Dalam perspektif umum, istilah spiritualitas berakar pada kata bahasa latin spiritus yang artinya nafas atau nafas kehidupan. Spiritualitas juga dapat berakar pada agama tetapi spiritualitas tidak sama dengan agama. ${ }^{18}$ Kamus Oxford Advanced Learner's Dictionary, mengartikan spiritual sebagai dimensi supranatural, persembahan, pernyataan, atau perasaan jiwa, kekudusan, sesuatu yang suci, pemikiran yang berkualitas, intelek dan sebuah kesadaran akan perubahan hidup serta berhubungan dengan organisasi keagamaan. Hal ini juga bisa diartikan sebagai inti yang mempengaruhi kehidupan manusia yang dimanifestasikan dalam pemikiran dan perilaku serta dalam hubungan atau relasi dengan diri sendiri, orang lain, Allah dan dengan Alam semesta. ${ }^{19}$ Jadi, seorang peserta didik memiliki spiritual ditunjukkan dengan mampunya ia menemukan suatu arti dan tujuan hidup, kemampuan dalam memahami kekuatan yang ada dalam diri sendiri serta mempunyai hubungan yang terikat antara diri sendiri dengan Tuhan.

\section{Faktor-Faktor yang Membentuk Karakter dan Spiritual}

Karakter dan spiritual dari peserta didik dipengaruhi oleh faktor-faktor yang berasal dari dalam (internal) dan luar (eksternal). Faktor internal berhubungan dengan kondisi jasmaniah (fisik dan kesehatan) ataupun psikologis. Psikologis berupa kecerdasan, minat dan perhatian, motivasi belajar, ketekunan, dan kebiasaan belajar. Faktor internal dapat mendukung dan atau menghambat peserta didik, karena faktor ini berasal dari masing-masing pribadi, yang akan timbul dengan sendirinya apabila ada kemauan untuk mensuport atau membangun pribadinya dalam mencapai hasil akhir yang diharapkan

\footnotetext{
${ }^{15}$ Kokom Komalasari and Didin Saripudin, Pendidikan Karakter (Bandung: Refika Aditama, 2017), 2.

${ }^{16}$ Masnur Muslich, Pendidikan Karakter Menjawab Tantangan Krisis Multidimensional (Jakarta: Bumi Aksara, 2011), 70.

${ }^{17} \mathrm{KBBI}$, "Spiritual," Kemendikbud, http://kbbi.web.id/spiritual.

${ }^{18}$ Noah Webster, Spiritual Menurut Kamus Webster, 1963.

19 Benny Hutahayan, Peran Kepemimpinan Spiritual Dan Media Sosial Pada Rohani Pemuda (Yogyakarta: CV Budi Utama, 2012), 24-25.
} 
atau bahkan sebaliknya menimbulkan degradasi moral. ${ }^{20}$ Artinya faktor internal dapat mempengaruhi kepribadian atau karakter dari peserta didik dalam belajar dan merespon materi pembelajaran yang ada, serta bergaul atau cerdas dalam membangun komunikasi dengan orang-orang yang ada di lingkungan sekitarnya.

Faktor eksternal yang memengaruhi hasil belajar dari peserta didik dapat bersumber dari keluarga, sekolah, dan lingkungannya. Keadaan keluarga sangat berpengaruh terhadap hasil belajar peserta didik itu sendiri karena pola pendidikan dalam keluarga sangat mempengaruhi perkembangan intelektual dari peserta didik. Faktor dari sekolah berasal dari tenaga pendidik, mata pelajaran, dan metode yang diterapkan. Faktor pendidik sangat berperan dalam terlaksananya pembentukan karakter dan spiritual karena cara pendidik menyampaikan materi dan respon pendidik dalam menyikapi materi yang diajarkan sangat mendukung pembentukan karakter serta spiritual peserta didik. Firdaus mengatakan lingkungan keluarga merupakan suatu lingkungan yang sangat berperan penting dalam diri setiap pribadi atau karakter dan spiritual dari masing-masing anak karena lingkungan keluarga merupakan lembaga pendidikan anak yang paling utama, sebab dalam keluarga inilah anak pertama kali memperoleh pendidikan dan bimbingan yang dapat mengarahkan mereka untuk memiliki masa depan yang baik. Artinya setiap dukungan atau motivasi yang diberikan kepada diri peserta didik baik itu melalui keluarga khususnya dan lingkungan sekitar, itu menunjukkan sikap diterimanya atau tidak kehadiran dari anak tersebut dalam keluarganya dan sekitarnya. ${ }^{21}$ Kedua faktor ini sangat berpengaruh terhadap pembentukan karakter maupun spiritual dari setiap peserta didik. Ketika kedua faktor di atas terpenuhi dengan baik akan memudahkan pendidik dalam menerapkan nilainilai yang berkaitan dengan pembentukan karakter dan spiritual kepada peserta didik baik dalam proses pembelajaran maupun dalam nilai-nilai kehidupan dari pendidik itu sendiri.

Selain itu, ada beberapa faktor lainnya yang mempengaruhi pembentukan karakter dan spiritual, antara lain: Pertama, perkembangan. Hal yang dimaksud adalah tahaptahap perkembangan seseorang, yang mana di setiap tahapnya memiliki kebutuhan spiritualitas yang berbeda, terkait keyakinan kepada Tuhan. Kedua, keluarga. Keluarga memiliki peran penting dalam memenuhi kebutuhan spiritual, karena di dalam keluarga

${ }^{20}$ Dianna Ratnawati, Bayu R. Setiadi, and Arifin Handoyono, "Faktor-Faktor Yang Mempengaruhi Pendidikan Karakter Holistic Siswa SMKN Di Kota Malang," Seminar Nasional Universitas PGRI Yogyakarta, 30.

\footnotetext{
${ }^{21}$ Ibid.
} 
terbangun ikatan emosional yang kuat dan selalu berinteraksi dalam kehidupan seharihari. Ketiga, perbedaan ras atau suku turut memengaruhi kebutuhan spiritual. Keempat, agama yang dianut. Keyakinan pada agama tertentu yang dimiliki oleh seseorang dapat memenuhi kebutuhan spiritual setiap individu. Kelima, kegiatan keagamaan sebagai penanda atau pengingat tentang relasi manusia dengan Tuhan Penciptanya. ${ }^{22}$

Dari penjabaran di atas, dapat disimpulkan bahwa pembentukan karakter dan spiritual seseorang dipengaruhi faktor internal dan eksternal. Faktor internal terdiri dari potensi spiritual, potensi emosional, potensi intelektual, dan potensi biologis yang ada dalam diri seseorang. Faktor internal yang dimaksudkan di sini adalah memengaruhi kehidupan pribadi sehingga memiliki hubungan yang terikat dengan Tuhan, mampu membedakan mana yang baik maupun buruk, memiliki arah dan tujuan hidup yang baik, serta dapat mengambil keputusan yang baik untuk kehidupannya. Sedangkan faktor eksternal yang membentuk karakter dan spiritual seseorang dikembangkan dari faktor internal itu sendiri yang terdiri dari lingkungan baik lingkungan sosial, dan lingkungan media. Faktor eksternal sangat mempengaruhi pertumbuhan dan perkembangan kepribadian seseorang terutama dalam pembentukan karakter yang positif maupun negatif. Kedua faktor ini memiliki keterkaitan dalam mempengaruhi pembentukan karakter dan spiritual setiap individu.

Jadi, pembentukan karakter dan pembentukan spiritual saling berkaitan. Pembentukan karakter menjadi hal yang sangat penting diajarkan pada peserta didik sejak dini. Sikap dan perilaku pendidik menjadi model bagi peserta didik untuk membangun kehidupan spiritual dan cara berperilaku, untuk itu pendidik seharusnya memiliki karakter dan spiritual yang baik dan benar. Mengajar bukan hanya sekadar keterampilan dan cakap dalam mengajar tetapi mengajar lebih dari itu, sehingga melalui peran pendidik dalam kemorosotan karakter dan spiritual dapat diperbaiki. Pembentukan karakter dan spiritual harus dilakukan secara holistik atau menyeluruh dan dilakukan secara terus menerus karena pembentukan dan pengembangan karakter dan spiritual terus berlanjut seumur hidup. Suprapto menjelaskan bahwa melalui pembentukan karakter maka peserta didik secara kognitifnya akan mengetahui tentang hal yang benar dan salah, secara efektif mereka akan mampu merasakan nilai yang baik dan perilaku yang baik sehingga mereka akan terbiasa untuk melakukannya. ${ }^{23}$

\footnotetext{
${ }^{22}$ Muchlisin Riadi, “Kebutuhan Spiritual Klien," Kajian Pustaka, last modified 2012, https://www.kajianpustaka.com/2012/10/kebutuhan-spiritual-klien.html.

${ }^{23}$ M. Kristiawan, Telaah Revolusi Mental Dan Pendidikan Karakter Dalam Pembentukan Sumber Daya Manusia Indonesia Yang Pandai Dan Berakhlak Mulia, n.d., 8.
} 


\section{Tantangan Pembentukan Karakter dan Spiritual Peserta Didik dalam Pembelajaran Daring di STT Tawangmangu}

Pada awalnya, pembelajaran daring mendapat respon positif dari peserta didik terutama pelaksanaannya yang fleksibilitas sehingga memberikan efek stimulant dalam proses kemandirian belajar. ${ }^{24}$ Meski demikian, dalam praktiknya pembelajaran daring ada banyak tantangan yang ditemukan terutama dalam pembentukan karakter peserta didik. Akibat pandemi Covid-19, sistem pendidikan pun dilaksanakan melalui jarak jauh atau Belajar Jarak Jauh (BJJ). Pembelajaran berbasis BJJ menemui problem baru, di mana pendidik dan peserta didik tidak bisa berinteraksi langsung. Yang menjadi sorotan utama dalam proses pembelajaran BJJ bukan mengenai transfer ilmu melainkan pada interaksi langsung yang di dalamnya terdapat keterkaitan emosional antara pendidik dan peserta didik. Di dalam interaksi langsung terdapat nilai-nilai yang ditanamkan pendidik yang berhubungan langsung dengan pembentukan karakter dan spiritual. Perubahan pembelajaran dari luring menjadi pembelajaran daring kurang efektif untuk membentuk karakter dan spiritual peserta didik.

Berdasarkan hasil observasi dan wawancara yang dilakukan oleh peneliti dengan peserta didik STT Tawangmangu dan dosen pengajar, peneliti menemukan tantangan dalam pembentukan karakter dan spiritual peserta didik pada proses pembelajaran daring di STT Tawangmangu, di antaranya ketidaksiapan institusi dan peserta didik dalam transisi pembelajaran dari konvensional ke pembelajaran daring. Hal ini mempengaruhi ketidaktersediaannya sarana dan prasarana dalam menunjang proses pembelajaran secara daring. Tidak hanya pada sarana dan prasarana melainkan juga berdampak bagi pendidik dalam melaksanakan proses pembelajaran, ditandai dengan minimnya metode yang digunakan dalam mengajar, ketidaksiapan pendidik dalam menggunakan IPTEK (Ilmu Pengetahuan Teknologi dan Komunikasi), dan materi yang disampaikan kurang maksimal.

Tantangan lain yang juga menjadi penghambat dalam proses pembentukan karakter dan spiritual dari peserta didik adalah alat komunikasi (laptop dan handphone). Banyak peserta didik mengeluh dengan adanya kekurangan ini, karena mereka tidak dapat mengikuti proses pembelajaran dengan baik. Terlihat dari peserta didik yang tidak semuanya mengaktifkan aplikasi yang digunakan oleh pendidik dalam proses pembelajaran yang diselenggarakan. Tentu hal ini memiliki pengaruh yang besar,

${ }^{24}$ Sri Gusty and Dkk, Belajar Mandiri : Pembelajaran Daring Di Tengah Pandemi COVID-19 (Medan: Yayasan Kita Menulis, 2020), 74. 
karena ketika mereka mengalami problem yang demikian maka mereka kehilangan konsentrasi terhadap pembelajaran dan bahkan sama sekali tidak memahami apa yang sedang disampaikan oleh pendidik.

Sedangkan tantangan lain yang menjadi kendala dalam pembentukan karakter dan spiritual peserta didik adalah dari bagian satuan pendidikan. Peneliti menemukan bahwa pihak satuan pendidikan atau sekolah, kurang siap dalam menyelesaikan permasalahan yang berkaitan dengan proses pembelajaran daring. dimana jaringan internet yang tidak menyupport, tidak adanya kuota dari peserta didik, alat komunikasi yang terbatas dari peserta didik, tidak adanya pengeras suara atau speaker. Pembelajaran daring memiliki indikator pencapaian yang sama dengan pembelajaran konvensional yang meliputi kognitif, afektif, dan psikomotorik namun hasilnya kurang maksimal karena banyak kendala dalam melaksanakan pembelajaran secara daring.

Berdasarkan tantangan pembentukan karakter dan spiritual dalam pembelajaran daring di STT Tawangmangu, maka peneliti menawarkan solusi untuk mengatasi tantangan yang ada di antaranya: Pertama, Penyelenggara pendidikan (institusi) perlu mengetahui pokok permasalahan yang dialami oleh pendidik dan peserta didik sebagai penghambat proses belajar mengajar. Sebagai pihak yang menyelenggarakan pembelajaran daring, maka harus memenuhi semua sarana dan prasarana proses pembelajaran daring. Di antaranya; seperti laptop, LCD, handphone, jaringan internet, speaker, ruang belajar yang nyaman dan alat pendukung lainnya. Tidak kalah penting, penyelenggara pendidikan perlu memberi edukasi kepada semua pendidik yang menyelenggarakan proses pembelajaran daring untuk menggunakan alat pembelajaran daring. Mengingat hasil observasi yang dilakukan peneliti juga menemukan bahwa Sebagian pendidik belum memahami penggunaan aplikasi pembelajaran yang ada.

Kedua, pendidik harus berinovasi. Menurut KBBI, inovasi adalah pemasukan atau pengenalan hal-hal yang baru dan pembaharuan. ${ }^{25}$ Berdasarkan pengertian itu dapat dimaknai bahwa inovasi merupakan proses penemuan baru (discovery) terhadap berbagai hal seperti pokok-pokok pemikiran dan cara kerja atau metode. Aktivitas pembelajaran merupakan kegiatan yang melibatkan peserta didik dalam membangun makna dan pemahaman. Dalam melaksanakan kegiatan pembelajaran yang berpusat pada peserta didik, pendidik harus menciptakan situasi yang dapat menimbulkan motivasi, tanggung jawab, serta dalam pembentukan karakter dan spiritual sehingga terjadi proses pembelajaran yang memiliki makna bagi peserta didik itu sendiri. Institusi bertugas menyediakan sarana dan prasarana dalam memenuhi kebutuhan-kebutuhan

${ }^{25} \mathrm{KBBI}$, “Inovasi,” Kemdikbud, https://kbbi.web.id/inovasi. 
lainnya dari proses pembelajaran. Sedangkan pendidik berinovasi dengan memanfaatkan sumber-sumber belajar baik yang disediakan oleh institusi maupun kreativitas dari pendidik dalam melaksanakan proses pembelajaran serta meningkatkan karakter dan spiritual peserta didik. Pendidik yang profesional harus mampu melakukan terobosan yang baru dan perubahan dalam melaksanakan pembelajaran daring. Terutama dalam mengupayakan pembentukan karakter dan spiritual peserta didik. Untuk itulah pendidik perlu berinovasi dalam melaksanakan proses pembelajaran daring. Misalnya pendidik memulai pembelajaran daring dengan doa bersama sebelum dan sesudah pembelajaran, materi pembelajaran dikemas dengan berbagai bentuk digital (video dll.) sehingga tidak membosankan. Dan di setiap akhir pembelajaran, hendaknya pendidik memberikan penguatan kepada peserta didik. Pendidik memberikan kesempatan kepada peserta didik untuk bertanya dan berpendapat. Pendidik juga perlu melakukan refleksi bersama peserta didik dengan apa yang sudah dilaksanakan dalam pembelajaran daring.

Ketiga, peserta didik harus memiliki kesadaran dalam diri pentingnya membangun karakter dan spiritual. Penting seorang peserta didik memiliki kesadaran dalam diri bahwa ia memiliki potensi-potensi (potensi internal yaitu potensi spiritual, potensi emosional, potensi, intelektual) yang harus dikembangkan. Semua potensi tersebut dapat dikembangkan oleh peserta didik dengan mengikuti pembelajaran daring. Dengan inisiatif yang tinggi dalam diri peserta didik untuk mengembangkan semua potensi dalam diri dengan cara membangun interaksi dengan pendidik maupun dengan teman sejawat. Sehingga peserta didik akan lebih mudah memahami materi pelajaran yang disampaikan oleh pendidik, serta peserta didik juga dapat dengan maksimal mengarahkan pola berpikirnya sesuai dengan metode atau gagasan yang baru (discovery) dari pendidik. Peserta didik harus memiliki motivasi belajar yang tinggi untuk mencapai hasil belajar yang maksimal seperti konsentrasi di dalam memahami materi ajar yang disampaikan. Menurut Azizah konsentrasi belajar akan membuat siswa memahami materi yang sedang diajarkan hal ini didasarkan karena perhatian akan tertuju pada apa yang sedang menjadi daya tarik peserta didik. ${ }^{26}$

Jadi, dalam pelaksanaan pembelajaran daring sangat penting memerhatikan faktor-faktor pembentuk karakter dan spiritual peserta didik. Satuan pendidikan, pendidik dan peserta didik harus bersinergi dalam melaksanakan pembelajaran daring.

${ }^{26}$ Yani Fitriyani and Dkk, "Motivasi Belajar Mahasiswa Pada Pembelajaran Daring Selama Pandemi Covid-19," Jurnal Kependidikan: Hasil Penelitian dan Kajian Kepustakaan di Bidang Pendidikan, Pengajaran dan Pembelajaran 6, no. 2 (2020): 169. 
Sehingga satuan pendidikan harus memenuhi tanggung jawab dalam menyediakan sarana prasarana yang digunakan dalam mendukung proses belajar mengajar daring. Dan pendidik harus berinovasi dalam memaksimalkan fasilitas yang ada untuk melaksanakan proses pembelajaran daring. Dan peserta didik harus memiliki kesadaran dalam dirinya untuk memotivasi diri untuk belajar dan mengembangkan semua potensinya.

\section{KESIMPULAN}

Berdasarkan pembahasan di atas, peneliti menarik kesimpulan bahwa pelaksanaan pembelajaran daring di Sekolah Tinggi Teologi Tawangmangu harus memperhatikan semua faktor-faktor pembentuk karakter dan spiritual. Jadi, solusi yang dapat dilaksanakan dalam pembelajaran daring untuk membentuk karakter dan spiritual diantaranya; Satuan pendidikan, pendidik dan peserta didik harus bersinergi dalam melaksanakan pembelajaran daring. Satuan pendidikan harus memenuhi tanggung jawab dalam menyediakan sarana prasarana yang digunakan dalam mendukung proses belajar mengajar daring. Dan pendidik harus berinovasi dalam memaksimalkan fasilitas yang ada untuk melaksanakan proses pembelajaran daring. Dan peserta didik harus memiliki kesadaran dalam dirinya untuk memotivasi diri untuk belajar dan mengembangkan semua potensinya.

\section{Referensi}

CNN Indonesia. “Jokowi Umumkan Dua Orang WNI Positif Corona Di Indonesia,” 2020. https://www.cnnindonesia.com/nasional/20200302111534-20-479660/jokowiumumkan-dua-wni-positif-corona-di-indonesia.

Fitriyani, Yani, and Dkk. "Motivasi Belajar Mahasiswa Pada Pembelajaran Daring Selama Pandemi Covid-19." Jurnal Kependidikan: Hasil Penelitian dan Kajian Kepustakaan di Bidang Pendidikan, Pengajaran dan Pembelajaran 6, no. 2 (2020): 169.

Gusty, Sri, and Dkk. Belajar Mandiri : Pembelajaran Daring Di Tengah Pandemi COVID-19. Medan: Yayasan Kita Menulis, 2020.

Hilna Putria dkk. "Analisis Proses Pembelajaran Dalam Jaringan (Daring) Masa Pandemi COVID-19 Pada Guru Sekolah Dasar." Basicedu : Jurnal of Elementary Education 4, no. 4 (2020): 862-863.

Hutahayan, Benny. Peran Kepemimpinan Spiritual Dan Media Sosial Pada Rohani Pemuda. Yogyakarta: CV Budi Utama, 2012.

KBBI. “Inovasi." Kemdikbud. https://kbbi.web.id/inovasi. 
_-_. "Spiritual." Kemendikbud. http://kbbi.web.id/spiritual.

Kemahasiswaan, Direktorat Pembelajaran dan, Direktorat Jenderal Pendidikan Tinggi, and Kementerian Pendidikan dan Kebudayaan RI. Panduan Penyelenggaraan Pembelajaran Semester Gasal 2020/2021 Di Perguruan Tinggi, 2020.

Kementerian Pendidikan dan Kebudayaan. "Surat Edaran Direktorat Jenderal Pendidikan Tinggi Kemdikbud Nomor 1 Tahun 2020." Last modified 2020. http://lldikti3.kemdikbud.go.id/v6/wp-content/uploads/2020/04/Surat-EdaranDirektorat-Jenderal-Pendidikan-Tinggi-Kemdikbud-Nomor-1-Tahun-2020-3.pdf.

Komalasari, Kokom, and Didin Saripudin. Pendidikan Karakter. Bandung: Refika Aditama, 2017.

Kristiawan, M. Telaah Revolusi Mental Dan Pendidikan Karakter Dalam Pembentukan Sumber Daya Manusia Indonesia Yang Pandai Dan Berakhlak Mulia, n.d.

Moleong, Lexy J. Metodologi Penelitian Kualitatif. Bandung: PT Remaja Rosdakarya, 2000.

Muslich, Masnur. Pendidikan Karakter Menjawab Tantangan Krisis Multidimensional. Jakarta: Bumi Aksara, 2011.

Ratnawati, Dianna, Bayu R. Setiadi, and Arifin Handoyono. "Faktor-Faktor Yang Mempengaruhi Pendidikan Karakter Holistic Siswa SMKN Di Kota Malang." Seminar Nasional Universitas PGRI Yogyakarta.

Riadi, Muchlisin. "Kebutuhan Spiritual Klien." Kajian Pustaka. Last modified 2012. https://www.kajianpustaka.com/2012/10/kebutuhan-spiritual-klien.html.

Sadikin, Ali, and Afreni Hamidah. "Pembelajaran Daring Di Tengah Wabah Covid-19." BIODIK : Jurnal Ilmiah Pendidikan Biologi 6, no. 2 (2020): 216.

Sanjaya, Ridwan. 21 Refleksi Pembelajaran Daring Di Masa Darurat. Semarang: Universitas Katolik Soegijapranata, 2020.

Santika, I Wayan Eka. "Pendidikan Karakter Pada Pembelajaran Daring." IVCEJ: Indonesian Values and Character Education Journal 3, no. 1 (2020): 8-16.

Simanihuru, Lidia, and Dkk. E-Learning. Medan: Yayasan Kita Menulis, 2019.

Tawangmangu, Sekolah Tinggi Teologi. Panduan Pembelajaran Daring, 2020.

Webster, Noah. Spiritual Menurut Kamus Webster, 1963.

Yuliani, Meda, and Janner Simamata. Pembelajaran Daring Untuk Pendidikan Teori Dan Penerapan. Medan: Yayasan Kita Menulis, 2020.

"Faktor-Faktor Yang Mempengaruhi Kesuksesan Pembelajaran Daring Dalam Revolusi Industri 4.0." SAINTEKS : Seminar Nasional Teknologi Komputer Dan Sains. 